\title{
PLUMMER VINSON SYNDROME - is it common in males?
}

\author{
Satvinder Singh BAKSHI
}

Received 23/2/2015

Accepted 1/4/2015

\begin{abstract}
Background - Plummer-Vinson syndrome is characterized by a triad of dysphagia, iron deficiency anemia and esophageal web. Most of the patients are middle aged women in the fourth to seventh decade of life. Objective - Very few cases of Plummer-Vinson syndrome affecting males have been reported. Here we report a series of male patients found to be suffering from Plummer-Vinson syndrome. Methods - Five males presented to us with dysphagia and fatigue of various durations, from April to August, 2012. Results - These patients were found to have iron deficiency anemia and esophageal web on subsequent investigations and were treated successfully with oral iron therapy. Conclusion - Plummer-Vinson syndrome is common in both males and females and can be successfully treated with oral iron therapy. The patients have an increased risk of developing gastrointestinal malignancies and should be thoroughly evaluated for the same.
\end{abstract}

HEADINGS - Plummer-Vinson syndrome. Iron deficiency. Anemia. Deglutition disorders. Men's health.

\section{INTRODUCTION}

Plummer-Vinson (PV) syndrome also called as Patterson Brown Kelly syndrome or Sideropenic dysphagia consists of a triad of dysphagia, iron deficiency anemia and esophageal webs. It was first described by Henry Stanley Plummer ${ }^{(14)}$ in the beginning of the 20 th century and later on by Porter Paisley Vinson ${ }^{(15)}$. Patterson and Kelly ${ }^{(3,8,10,12,13)}$ were the first to describe the clinical signs and symptoms namely anemia, dysphagia, glossitis, cheilitis, iron deficiency anemia and koilonychia. PV mainly affects white women in the 4th-7th decade ${ }^{(3,10)}$. It has rarely been described in males, here we describe a series of five middle aged male patients, who presented to us with dysphagia and iron deficiency anemia, which on radiological and endoscopic evaluation turned out to be having PV syndrome.

\section{METHODS}

All the five male patients presented to us in the ENT opd from April to august 2012 with varying durations of dysphagia, which was gradually progressive and more to solids. The average age of the patients was 44.2 years and the average duration of symptoms was for 3 months. In addition they also had symp- toms suggestive of anemia like fatigue and tiredness. On examination all were found to be pale with signs of iron deficiency anemia like glossitis, cheilitis and koilonychias (Figure 1). Videolaryngoscopic and neck examinations were found to be normal. The hematological investigations (Table 1) revealed an average $\mathrm{Hb}$ of $5.16 \mathrm{~g} / \mathrm{dL}$ (12-14), Average MCV $71.6 \mathrm{fl}$ (80-95), Average MCH 23.4 pg/dL (27-32), Average serum Iron $25.8 \mathrm{mcg} / \mathrm{dL}$ (40-65), Average total iron binding capacity (TIBC) $485 \mathrm{mcg} / \mathrm{dL}(245-450)$ and average

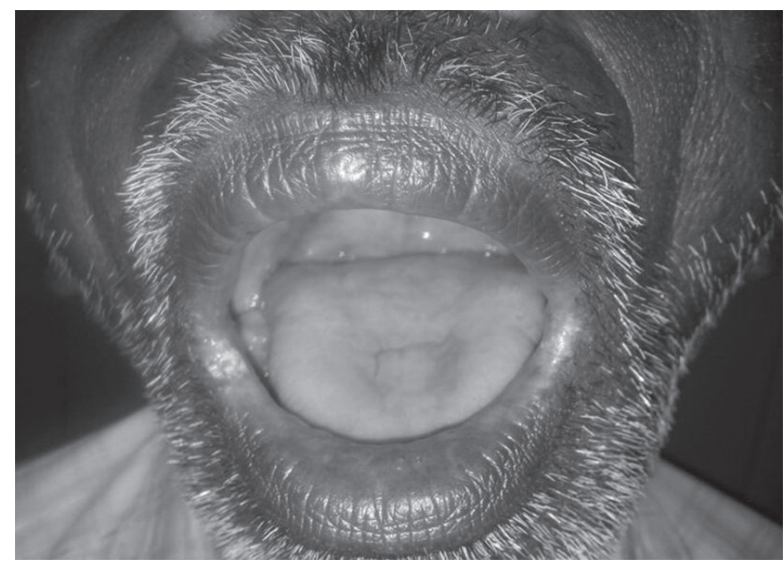

FIGURE 1. Male patient with glossitis and chielosis

Declared conflict of interest of all authors: none

Disclosure of funding: no funding received

Author disclosure statement: no competing financial interests exist

Research performed at: Jawaharlal Institute of Postgraduate Medical Education \& Research (JIPMER), India.

Correspondence: Satvinder Singh Bakshi. Assistant Professor of Ear, Nose \& Throat (ENT). Dept of ENT and Head \& Neck Surgery. Mahatma Gandhi Medical College and Research Institute. Pillaiyarkuppam, Pondicherry. 607402 - India - E-mail: saty.bakshi@gmail.com 
TABLE 1. Table showing the age, duration of symptoms, hematological parameters and length of stricture of all the patients

\begin{tabular}{lccccccccc}
\hline S. No. & $\begin{array}{c}\text { Age } \\
\text { (years) }\end{array}$ & $\begin{array}{c}\text { Duration of } \\
\text { symptoms } \\
\text { (months) }\end{array}$ & $\begin{array}{c}\text { Hb } \\
(12-14 \mathrm{~g} / \mathrm{dl})\end{array}$ & $\begin{array}{c}\text { MCV }(80- \\
95 \mathrm{fl})\end{array}$ & $\begin{array}{c}\text { MCH } \\
(27-32 \mathrm{pg})\end{array}$ & $\begin{array}{c}\text { Serum Iron } \\
(40-165 \\
\text { mcg/dL) }\end{array}$ & $\begin{array}{c}\text { TIBC } \\
(245-450 \\
\text { mcg/dL) }\end{array}$ & $\begin{array}{c}\text { Ferritin } \\
(30-300 \\
\text { ng/mL) }\end{array}$ & $\begin{array}{c}\text { Ba swallow } \\
(\text { length of } \\
\text { stricture in cm) }\end{array}$ \\
\hline Patient A & 40 & 3 & 6.4 & 75 & 25 & 42 & 485 & 20 & 1.2 \\
Patient B & 51 & 2 & 4.2 & 68 & 22 & 30 & 495 & 18 & 1.5 \\
Patient C & 43 & 4 & 5.2 & 72 & 24 & 35 & 480 & 20 & 2.2 \\
Patient D & 45 & 4 & 4.6 & 70 & 24 & 32 & 490 & 18 & 1.6 \\
Patient E & 42 & 2 & 5.4 & 73 & 22 & 30 & 475 & 24 & 1.8 \\
Average & 44.2 & 3 & 5.16 & 71.6 & 23.4 & 25.8 & 485 & 20 & 1.66 \\
\hline
\end{tabular}

Ferritin levels $20 \mathrm{ng} / \mathrm{mL}$ (30-300). The peripheral smear of all the patients showed microcytic hypochromic red blood cells with anisocytosis. Barium swallow (Figure 2) showed a smooth filling defect suggestive of a web in the cricopharynx with an average length of $1.66 \mathrm{~cm}$, this was also confirmed by doing upper gastrointestinal endoscopy on all the patients.

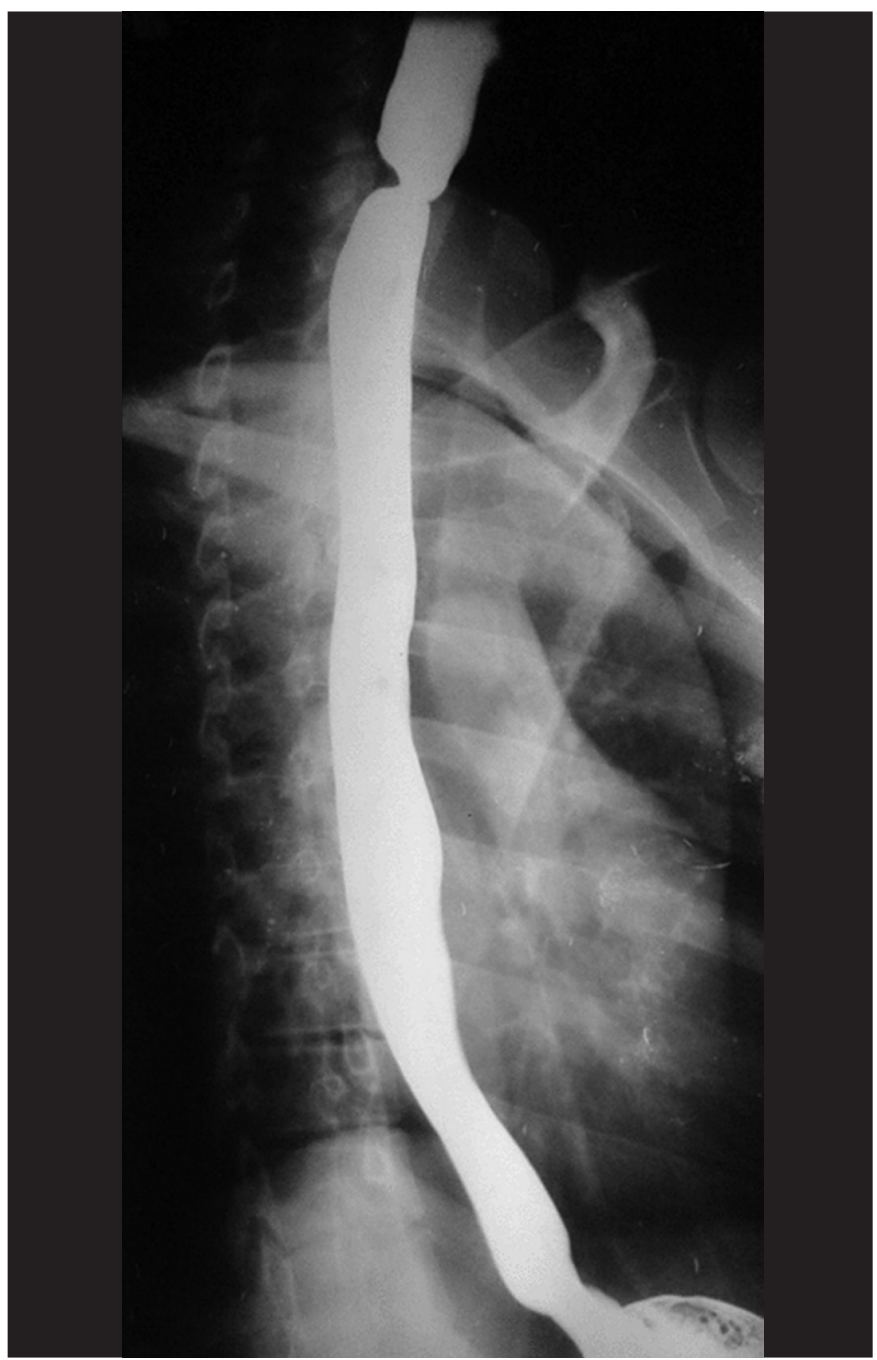

FIGURE 2. Barium swallow showing the esophageal web
All the patients received oral iron therapy with $120 \mathrm{mg} /$ day for 8-14 weeks (average 11 weeks), one of the patient had to be transfused two units of paced cells to improve his general condition. All the patients were given dietary advice and showed improvements in their symptoms by the end of 1 month of treatment. The iron supplements were continued till the hemoglobin levels reached $14 \mathrm{~g} / \mathrm{dL}$. All the patients are still under follow up and have no further complaints and their nutritional status is good.

\section{DISCUSSION}

Although the triad of PV syndrome has decreased in the west, due to improvement in nutrition, health care and decreased pregnancy ${ }^{(3,12)}$ but it is still relatively common in the Indian subcontinent. Patients present with slowly progressive dysphagia and symptoms of iron deficiency anemia like weakness, pallor, fatigue, which may dominate the clinical picture ${ }^{(9,10)}$. Patient may have glossitis, cheilitis and koilonychias ${ }^{(3)}$. The diagnosis is made by evidence of iron deficiency anemia and detection of esophageal web by Barium swallow, video fluoroscopy or upper GI endoscopy. Barium radiography is the most sensitive test to diagnose esophageal webs ${ }^{(7)}$. Esophageal web is a thin $2-3 \mathrm{~mm}$ membrane, covered with pink mucosa, consisting of mucosa and sub mucosa without the inclusion of muscle layer causing mechanical dysphagia ${ }^{(6,11)}$. Webs are usually eccentric, semi lunar or annular and present with dysphagia if the diameter of the lumen through the web is less than 12 millimeters. It occurs in a proximal 4 or 5 centimeters of esophagus and may be difficult to diagnose during endoscopy if it is located just beyond the cricopharyngeus muscle ${ }^{(6)}$.

The etiopathogenesis of PV syndrome is unclear however various mechanisms have been proposed like genetic preponderance, autoimmune disorder and iron deficiency anemia. PV syndrome has been reported to be associated with various auto immune disorders like rheumatoid arthritis, thyroditis, pernicious anemia or celiac disease $e^{(3,4,10)}$, however iron deficiency anemia seems to be the most likely cause by most authors. Iron deficiency can precede the dysphagia ${ }^{(13)}$. The alimentary tract is susceptible to iron deficiency since it rapidly loses iron dependant enzymes due to its high cell turnover, this may cause mucosal degeneration, muscle atrophy and web formation. 
First step in the management of PV syndrome is to detect the cause of iron deficiency, which is mostly increased menstrual flow in females. In males however an underlying malignancy causing blood loss should be ruled out. PV syndrome is a pre malignant condition and there is an increased risk of esophageal and pharyngeal cancer which is approximately $3 \%-15 \%{ }^{(1)}$ therefore surveillance with UGIE every year has been advised. Treatment consists of correcting the underlying iron deficiency anemia and mechanical dilatation using endoscopic bougies or pneumatic balloons, the webs can also be excised. Some studies have shown that iron supplementation alone can relive the symptoms ${ }^{(5)}$ this also holds true for our cases where the patient's symptoms improved on iron therapy and no mechanical dilatation was required.
Prognosis of PV syndrome is good, dysphagia and iron deficiency anemia can be treated easily and effectively.

\section{CONCLUSION}

Plummer Vinson syndrome is characterized by dysphagia, iron deficiency anemia and esophageal webs and is common in both males and females. Although the incidence has been decreasing in the western population, but the prevalence in the Indian subcontinent is still high. It is a pre malignant condition and thorough investigations should be done to rule out development of malignancy at the site of web and detect any malignancy causing the anemia especially in males with PV syndrome.

Bakshi SS. Síndrome de Plummer Vinson - é comum em homens? Arq Gastroenterol. 2015,52(3):250-2.

RESUMO - Contexto - A síndrome de Plummer-Vinson é caracterizada por uma tríade composta por disfagia, anemia por deficiência de ferro e anel esofágico. A maioria dos pacientes são mulheres da quarta à sétima década de vida. Objetivo - Muito poucos casos de síndrome de Plummer-Vinson afetando homens têm sido relatados. Relata-se aqui uma série de pacientes do sexo masculino com síndrome de Plummer-Vinson. Métodos - Entre abril a agosto de 2012, cinco pacientes do sexo masculino, com sintomas de disfagia e fadiga de duração variada, foram investigados. Resultados - Em todos foram encontrados anemia por deficiência de ferro e anel esofágico em investigações posteriores e foram tratados com sucesso com terapia oral de ferro. Conclusão - A síndrome de Plummer-Vinson é comum em ambos os sexos e pode ser tratada com sucesso com terapia oral de ferro. Como estes pacientes têm risco aumentado de desenvolver neoplasias gastrointestinais, devem ser cuidadosamente avaliados.

DESCRITORES - Síndrome de Plummer-Vinson. Deficiência de ferro. Anemia. Transtornos de deglutição. Saúde do homem.

\section{REFERENCES}

1. Chisholm M. The association between webs, iron and post-cricoid carcinoma. Postgrad Med J. 1974, 50(582):215-9.

2. Dantas RO, Villanova MG. Esophageal motility impairment in Plummer-Vinson syndrome. Correction by iron treatment. Dig Dis Sci 1993;38(5):968-71.

3. Demirci F, Savas MC, Kepkep N et al. Plummer-Vinson syndrome and dilatation therapy: A report of two cases. Turk J Gastroenterol. 2005;4:224-7.

4. Dickey W, McConnell B. Celiac disease presenting as the Patterson-Brown Kelly (Plummer-Vinson) syndrome. Am J Gastroenterol 1999;29:291-2.

5. Hoffmann RM, Jaffe PE. Plummer-Vinson syndrome. A case report and literature review. Arch Intern Med. 1995;155(18):2008-111.

6. Jani PG. Plummer-Vinson Syndrome: Case Report. East Afr Med J. 2001;78(6):332-3
7. Jason FV, Micheal FV. The Esophagus: anatomy, physiology and diseases Cummings Otolaryngology-Head \& Neck Surgery. 4th ed. Philadelphia: Elsevier Mosby; 2005. p. 1835-55

8. Kelly AB. Spasm at the entrance of the esophagus. J Laryngol Otol. 1919;34:285-9.

9. Khan FY, El-Hiday AH, Morad NA. Plummer-Vinson syndrome associated with solid pseudopapillary tumor of the pancreas. Chin Med J. 2007;120:1553-5.

10. Kim KH, Kim MC, Jun GJ. Gastric cancer occurring in a patient with Plummer-Vinson syndrome: A case report. World J Gastroenterol. 2005; 11:7048-50.

11. Mohamed IY. Treatment of Plummer-Vinson syndrome with Savary-Gilliard dilatation. Saudi Med J. 2004;25(4):524-6.

12. Novacek G. Plummer-Vinson syndrome. Orphanet J Rare Disease. 2006;1:36.

13. Paterson DR. A clinical type of dysphagia. J Laryngol Otol. 1919;34:289-91.

14. Plummer HS. Diffuse dilatation of the esophagus without anatomic stenosis (cardio spasm). A report of 91 cases. JAMA 1912;58:2013-5.

15. Vinson PP. A case of cardiospasm with dilatation and angulation of the esophagus Med Clinics North Am. 1919:3:623-7. 